anthropology \& materialism

\section{Anthropology \& Materialism}

A Journal of Social Research

Special Issue | I | 2017

Discontinuous Infinities

\title{
The Pure Act of Recollection
}

Walter Benjamin and Maurice Blanchot Reading Proust

\section{Yanik Avila}

\section{(2) OpenEdition}

\section{Journals}

Electronic version

URL: http://journals.openedition.org/am/817

DOI: $10.4000 / a m .817$

ISSN: 2364-0480

Publisher:

CETCOPRA, CRASSH - Center for Research in the Arts Social Sciences and Humanities, Fakultät Gestaltung - Universität der Künste Berlin

Electronic reference

Yanik Avila, "The Pure Act of Recollection », Anthropology \& Materialism [Online], Special Issue I

I 2017, Online since 02 March 2017, connection on 30 April 2019. URL : http:// journals.openedition.org/am/817; DOI : 10.4000/am.817

This text was automatically generated on 30 April 2019.

Tous droits réservés 


\title{
The Pure Act of Recollection
}

\author{
Walter Benjamin and Maurice Blanchot Reading Proust
}

\author{
Yanik Avila
}

1 For Walter Benjamin, as for Maurice Blanchot, the philosophical stakes linked to literature as a specific discourse or mode of language lie in the problematic status it assigns to subjectivity. In the context of his early literary studies, working on Goethe's Elective Affinities, Benjamin postulates a "basic law of literature", which states that within a literary work "truth content" [Wahrheitsgehalt] and "material content" [Sachgehalt] initially intertwine. ${ }^{1}$ According to Benjamin, it is the task of critique to aim at truth content, and thereby to extract the work from its embedding in a 'real' world. Moreover, the process of this extraction is the measure of the historical time encapsulated in the work, as Benjamin writes, using a Bergsonian term: its "duration". ${ }^{2}$

As Michel Foucault suggests, for Blanchot, the utterly reduced, pure self-assertion of the literary discourse of modernity - its refusal to be limited by any meaning or communication that could be subtracted from its form - can be seen as the "breakthrough to a language from which the subject is excluded". ${ }^{3}$ This event is manifest in the paradoxical ontological structure of the work of art, more particularly the literary work, as Blanchot approaches it.

3 However different they may appear, these two figures of thought are both organised around a fundamental separation that excludes the 'work', the literary work, from the world of realities, and hence from the course of history, of subjectivity qua historical action. Nevertheless, it is through this very exclusion that both Blanchot and Benjamin aim at another dimension of historicity, one in which the work refuses to relate to the subject, to a transcendental and thus a-historical subject, namely: the subject of the (Kantian) transcendental synthesis. The very structure of literary works implies a thorough resistance to history - understood here as the realm of subjective actions, of purposes and progression in time. By refusing to relate to productive subjectivity, literary works refuse to coincide with subjective purposes, and are therefore at odds with the very idea of a transcendental (and thus naturalised) subject of history - a privileged point of view that holds everything together. ${ }^{4}$ However, this refusal, for Benjamin as for 
Blanchot, takes place when the discourse of literature, bereft of its ties to a real, i.e. experienceable historical world, repeats the pure (and hence empty) gesture of transcendental synthesis. As the reduplication, or simulation of a synthetic activity without a subject, literature, thus at once transforms the inmost intimacy of consciousness into an extreme exteriority.

Marcel Proust's work À la Recherche du temps perdu puts precisely this gesture to the test because it represents a comprehensive attempt at transforming pure consciousness into narration. As such it confronts the subject of reading with an experience that, in its immanence, is radically unapproachable. It is in deciphering this unapproachability of experience as part of the predicament of subjectivity in modernity that Benjamin and Blanchot, in their readings of Proust, propose notions of historical cognition that hinge on the instant where the subject of historical action is inverted into its image, into the utter passivity that is ascribed to nature.

\section{Benjamin (I): Body-Space}

5 One of Benjamin's main claims in his 1929 essay, "Surrealism: The Last Snapshot of the European Intelligentsia", refers to an instant of "bodily collective innervation" that emerges from the coinciding of a "sphere of images" and a "sphere of bodies". ${ }^{5}$ It seems that this juxtaposition implies a trope, a metaphorical operation. Benjamin outlines this metaphorical nexus more explicitly elsewhere, in a note contained in "Convolute K" of the Arcades-Project, in which he considers a transformation of a particular realm that could be described as 'second nature' into history proper. Invoking a basic assumption of psychoanalysis, he spells out its implications in terms of the opposition of sleeping and waking:

It is one of the tacit suppositions of psychoanalysis that the clear-cut antithesis of sleeping and waking has no value for determining the empirical form of consciousness of the human being, but instead yields before an unending variety of concrete states of consciousness conditioned by every conceivable level of wakefulness within all possible centers. ${ }^{6}$

While the metaphorical operation in the essay on Surrealism modifies the meaning of the term 'body' - "The collective is a body, too" - the decisive term here is 'consciousness'. But it is not the account of a transcendental consciousness, as defined by the Cartesian tradition of a philosophy of mind in terms of a res cogitans without extension; rather, the 'form' of consciousness, which is at stake here, is one that Benjamin refers to as 'empirical'. 8 The aim is thus to undo the separation between body and consciousness, to see it as a result rather than an essential factor. This view links Benjamin's account of consciousness to one of the main insights of psychoanalysis: the idea of an immanent consciousness, i.e. a consciousness that is not separable from its alleged other, the body, and therefore endowed with extension. In the terminology of Freudian metapsychology this supposition finds a rather concise formulation: it is the assumption that "mental life is the function of an apparatus to which we ascribe the characteristics of being extended in space and of being made up of several portions [...]." However, by avoiding a transcendental account of consciousness - an account in which the unity of consciousness is secured by a sphere of pure noumena, which govern the (individual) body from a sovereign place external to $\mathrm{it}^{10}$ - Benjamin (as well as Freud) challenge the very notion of an individual body and its unity. 
7 As a corollary of this conception of consciousness, we find an idea, or rather an image of the individual body, which is already a fiction: an internal space or landscape - the result of a process of extension, inflation and magnification of the space of the body. Viewed against this background, the operation that Benjamin performs is by no means altogether exterior to the psychoanalytic premise. Even if he goes on to formulate it in the vocabulary of an established "situation", ${ }^{11}$ the transfer here is by no means a mere metaphor, since such a metaphor would rely on an already constituted individual mind occupying a sovereign position. Moreover it would presuppose a body that constitutes itself as one, i.e. as a coherent entity that is attributable to the mind and is, at least in principle, at its command. Rather, spelling out the implications of psychoanalysis' immanent conception of mental life, Benjamin seems to focus on the very movement the shift of the boundary between mind and body - between consciousness and a corporeality that constitutes itself by evading the intentionality of consciousness in a manner that makes it appear as nature. It is here that Benjamin suggests a conception of the unconscious that is eminently historical, or, more appropriately perhaps: an idea of history that redefines the relation of consciousness to a sphere of being-in-itself, which Benjamin names 'nature', a relation that, for the time being, is given as a strict separation:

Of course, much that is external to the former [the individual] is internal to the latter [the collective]: architecture, fashion - yes, even the weather - are, in the interior of the collective, what the sensoria of organs, the feeling of sickness or health, are inside the individual. And so long as they preserve this unconscious, amorphous dream configuration, they are as much natural processes as digestion, breathing, and the like. They stand in the cycle of the eternally selfsame, until the collective seizes upon them in politics and history emerges. ${ }^{12}$

8 'History' therefore emerges as an event that takes place at the very juncture between consciousness and its outside. This outside is perhaps more internal than the traditional subject-object paradigm of the philosophy of mind suspects. If the mind is composed of several portions, of multiple extended elements that relate to, communicate with, confine and restrict each other, then this consciousness becomes a body-space that is essentially itself an exteriority, an outside. The direction of the interrogation might therefore also have to be reversed; one would no longer have to ask: how is a collective body conceivable? Instead one would have to ask: what is the nature of this fiction, that is, the fiction of the individual, self-contained body?

\section{Blanchot (I): Imaginary Space}

In his television interview, L'abécécaire, ${ }^{13}$ when prompted by Claire Parnet to comment on the letter 'D' (as in 'desire'), Gilles Deleuze formulates a resolute objection to an abstract notion of desire, which, he claims, is maintained by psychoanalysis. Its abstractness lies in the idea that desire is and has to be directed at an object - something or somebody - that can be isolated. In contrast, Deleuze takes his cue from Proust when he says that desire, in fact, cannot but take place within an assembly, an aggregate [un agencement]. He reminds us of the way in which Proust's objects of desire, be they persons or things, are always framed by the spaces in which they appear - objects that are tied to their background or, as it were, enveloped by landscapes, drawing all their affective substance from such framing. Here Deleuze's description resonates with Benjamin's account, referenced above, of the shift from the individual body to the collective, from nature to history. Like 
Deleuze, Georges Poulet, in his 1963 study on Proustian space, points out this localebound quality of Proust's characters:

Without the locales, the characters would be mere abstractions. The locales specify their image and provide us with the necessary support thanks to which we can assign them a place in our mental space, dream of them, and remember them. ${ }^{14}$

10 However, the philosopher Deleuze seems to go one step beyond Poulet's philological observation when he makes a claim about the structure of desire tout court. While Poulet speaks of a 'mental space' that is extracted from the world of objects, reproducing them as 'images', Deleuze claims that what he calls 'assembly' is not the object of desire, since desire is not external to it, but indissolubly interwoven with it. The contrast becomes all the more visible when Poulet affirms a substantial difference between the exteriority of the characters in Proust's narration and the interiority of the 'central consciousness', which is that of the narrator: "Oddly enough, this novelist of interiority relentlessly forces himself to present his personages (with the exception of one, the central consciousness) in terms of exteriority." ${ }^{15}$ For Deleuze, it seems, desire works across the separation between the imaginary and the real, between reading and experiencing; but if the subject of desire is immanent to the text to begin with, if it is, ultimately, identical with the unfolding of the narration, it is because narration itself, for Deleuze, does not pose a problem. For Poulet, however, it does. But he sidesteps its consequences by granting the central consciousness - the subject of narration - the interiority that the objects are lacking, as if, in turn, it presented an immediate interior experience. But the intensification of this interiority through the immanence of narrative must lead to the point where it is no longer the interiority of a subject, but rather pure interiority; and as such it is inverted into an utter exteriority, into text. This inversion is the pivotal point for Maurice Blanchot's reading of Proust.

11 For Proust, the production of experience through an unfolding of narration seems to be the aesthetic ambition at the heart of $\grave{A}$ la Recherche du temps perdu. In his essay on "The Experience of Proust", Maurice Blanchot is concerned with the question of a "pure narrative", ${ }^{16}$ as posed in Proust's writing. What does 'pure narrative' mean? Blanchot seems to suggest that it can be understood when compared with the form of the novel. That is to say, Blanchot invests the novel as a literary form with a very specific ambition: that of presenting a world which is a consistent, albeit fictional whole; a world which appears capable of subsisting beyond its being-narrated. A 'pure narrative', by contrast, would be one that renounces this ambition. It might, however, be eclipsed by the material content of a given narrative, its "novelistic density". ${ }^{17}$ While every novel, incidentally, relies on this narrative gesture so that it can come into being, the very consistency and self-sufficiency of the narrated world conceals its origin in this gesture. At first sight, what could be called the 'autobiographical illusion' in Proust's novelistic undertaking is what removes him furthest from the realisation of precisely this goal: "While the imaginary journey of narrative leads other writers into the unreality of a scintillating space, for Marcel Proust everything happens as if it were fortunately superimposed onto the journey of his actual life." 18 In other words, what appears to be Proust's 'actual life' provides the subject matter, an elusive place exterior to narration, where the reality of things ensures the consistency of the narrated events. However, the space of Proust's narration (which Blanchot goes on to characterise as "imaginary space"19) is anything but real if reality implies homogeneity and continuity. The narration is unleashed (again and again) by events that constitute a veritable short-circuiting of a homogenous and 
continuous, objective and objectifiable timeline. The material of narration is composed of what Proust terms 'sensations', which essentially consist of a synthesis that, as it were, "abolishes time". ${ }^{20}$

Blanchot cites the instance in which the narrator stumbles over the irregular cobbles that line the Guermantes' courtyard. He points out that the memory of the stumbling in the Baptistery of San Marco is by no means a duplication of the original event, but the actual, original event itself:

Yes, he [the narrator] asserts, time is abolished, since, at once, in a real act of capturing [...] I hold the Venice instant and the Guermantes instant, not a past and a present, but one single presence that causes incompatible moments, separated by the entire course of lived life, to coincide in a palpable simultaneity. ${ }^{21}$

This 'palpable simultaneity' introduces an irreducibly metaphorical structure into time, or, more precisely, into the time defined by 'the entire course of lived life'. 'Lived life' thus becomes conceivable as the essence of a separation that fuses two unrelated objects into one sensation. 'Sensation' is nothing but the positive substance of this absence. To be sure, as a 'sensation', this "event" is itself a psychological event, as Blanchot remarks in a footnote. ${ }^{22}$ But whose psyche is envisaged here? Who if not the narrator, defined as the very subject to whom these sensations can be attributed? Transforming these sensations into narration thus means emptying the space between the instants of recollection - of involuntary memory - to empty it of everything that entrenches them in the reality of a conscious subject in the domain of voluntary memory and intelligence. Rather than being events 'within' time, narration transforms those 'psychological' entities into fields that have an extension of their own, an extension in time, but in a transformed time, an imaginary time, manifesting what Blanchot calls "the incomparable, unique ecstasy of time." ${ }^{23}$

Blanchot arranges his argument around a comparison between the style of $\grave{A}$ la Recherche $d u$ temps perdu, on the one hand, especially the decisive final experience narrated in Le temps retrouvé, and, on the other hand, a similar event narrated in the posthumously published novel Jean Santeuil, which could be seen as a precursor or, as Blanchot calls it, a rejected "draft." ${ }^{24}$. For Proust, as Blanchot reads him, Jean Santeuil fails to produce the experience at which it aims precisely because it preserves a much greater proximity to the "actual Proust". ${ }^{25}$ By contrast, the experience that is at stake for Proust necessitates the complete metamorphosis of the narrator, through which he not only enters a space of radical exteriority but also the domain of the whole, which is at once the space of the image, and accordingly the transformation of time into an imaginary space. ${ }^{26}$ If the Kantian notions of time and space as forms of inner and outer intuition define, in their clear-cut distinctness, the ability to experience individual, empirical subjectivity, then it is the merit of Proust's writing to reflect the becoming-image, the pure exteriority of time as the essence of writing: "the transformation of time into an imaginary space (the space unique to images) [...]: that remoteness and distance that make up the milieu and the principle of metamorphoses and of what Proust calls metaphors." ${ }^{27}$ Proust's experience is thus hermetically enclosed in the psyche of the narrator. But the narrator's (fictional) interiority is, in turn, congealed in the radical exteriority of writing, of the narrative and its temporality.

[T] he time of the narrative, when, although he says 'II' it is no longer the real Proust or the writer Proust who has the ability to speak, but their metamorphosis into that shadow that is the narrator turned into a 'character' of the book, the one who in the story writes a story that is the work itself. ${ }^{28}$ 
What Proust calls 'sensation' is no longer the sensation as it pertains to a self-contained subject. Rather, its artificiality - part of an "almost sacred reality" ${ }^{29}$ - reveals its allegorical structure, its structure as writing. ${ }^{30}$ Adapting Deleuze's thought on desire, 'pure narrative' thus seems to mean a narrative that narrates only narrating, i.e. the continuous detachment of both the world as subject matter and the self as subject (qua internal relation to the world, qua representation etc.) from themselves. This metamorphosis of the narrator for Blanchot constitutes the "movement of the book toward the work" ${ }^{\prime 1}$ - the œeuvre - which is at once, one must add, the manifestation of an utter désceuvrement. Constituting every single thing as a whole, as being one, the imaginary seems to be at once the power of the synthesising subject, and the basis of its utter powerlessness. It is a power, the power to act as a historical, empirical subject so long as the assembly that governs its desire has not condensed into an appearance, so long as it is not, strictly speaking, one; but where this power of the subject (the imaginary) appears as being integrated into one, i.e. wherever it - and with it a whole, empirical, lived life - becomes the material of a narration, this subjectivity, whilst it is still presented as historical, owes its being to its utter passivity, its utter separation from history. For what turns into an image is not this or that object, which would thereby constitute a mere representation; rather it is the object-relation itself, that intimate space of the empirical subject, which congeals into an image of itself - one that can only take the shape of pure narration.

The twist by which, for Blanchot, Proust transforms the separation from the world into a positive experience - the experience of pure narrative - echoes the way in which Benjamin locates the original problem of Proust at the junction of psychological concerns and narration. How so?

\section{Benjamin (II): Involuntary memory and "the issueless private character of Man's inner concerns"}

17 In his study "On Some Motifs in Baudelaire", Benjamin introduces Proust as an heir to Henri Bergson, linking his novelistic project to the latter's notion of duration - 'durée' as developed in Matière et Mémoire. As Bergson's title indicates, the concept of duration as experienced time is closely intertwined with a theory of memory. However, Benjamin reads Bergson's attempt to establish a theoretical account of experience against the background of a historical situation that is marked by the progressive and irretrievable loss of experience. Situating him within the context of the nineteenth century tradition of a philosophy of life [Lebensphilosophie] which stretches from Dilthey to Klages and Jung, Benjamin points out that Bergson's own attempt to restore an authentic experience, which is fundamentally different from its current forms in the "standardized, denaturated life of the civilized masses", ${ }^{32}$ nonetheless disavows the very particularity of the social situation out of which, and against which it was deployed. Indeed, according to Benjamin, Bergson's philosophy has to be regarded as the "afterimage", which appears to the eye when it shuts out the experience of the "age of big-scale industrialism". ${ }^{33}$ Benjamin's formulations here suggest that the very structure of duration as a form of experience requires one to think about the nexus between poetic fiction and the structure of subjectivity that it implies: "Matière et mémoire defines the nature of 
experience in the durée in such a way that the reader is bound to conclude that only a poet can be the adequate subject of such an experience." ${ }^{34}$

Unlike Blanchot, Benjamin does not explicitly differentiate between the poet as a (historical) subject and poetic subjectivity, nor does he explicitly name the problem of the narrator, and of narrative, as being crucial to the argument. But it is the same space that Benjamin envisages, one in which narrative is detached from any related object or event, from a self-contained experience beyond narration, where, therefore, it affects every narrated object in its very objecthood. Reformulating Benjamin's assertion, it is thus the desœuvrement for which poetic subjectivity provides the model, which defines the structure of Bergson's concept of experience. However, while Proust's project shares the social and historical determinants of Bergson's philosophy, Bergson's merely theoretical approach treats an (ultimately unavailable) experience as if it was immediately available. By contrast, it is Proust's fundamental ambition to produce the experience in question artificially or, as Benjamin writes, synthetically: "Proust's work À la Recherche du temps perdu may be regarded as an attempt to produce experience synthetically, as Bergson imagines it, under today's conditions, for there is less and less hope that it will come into being naturally." ${ }^{35}$

Benjamin repeatedly suggests that Proust's work should be considered as beginning with the utter artificiality of the narrative situation which it presupposes. If this production of synthetic experience takes the shape of a comprehensive attempt "to restore the figure of the storyteller to the present generation, ${ }^{36}$ then it is because for Benjamin the practice of storytelling is the epitome of that synthetizing activity that constitutes the notion of experience as embedded in a life: "[i]t is not the object of the story to convey a happening per se, which is the purpose of information; rather, it embeds it in the life of the storyteller in order to pass it on as experience to those listening." ${ }^{37}$ Here, the storyteller's life as an organic whole composed of meaningful elements is what brings forth the story as a meaningful, coherent experience, i.e. as narration: "It [the story] bears the marks of the storyteller much as the earthen vessel bears the marks of the potter's hand." 38 However, the marks of the storyteller's life in Benjamin's analogy would be an element that precisely hinders the completion of what Blanchot called the 'metamorphosis of the narrator'. The 'restoration' of the storyteller that Benjamin emphasises has to take into account the fundamental transformation that he, the storyteller, undergoes in this process: as a "figure", where the "resurrection of the past" takes the shape of the "imaginary past of an already entirely imaginary being." ${ }^{39}$ The fact that, according to Benjamin, it is a restoration "to the present generation" highlights the historical index that determines the specific experience at stake, experience "under today's conditions." 40

In Benjamin, this problem shines through; for there is a peculiar equivocation in the concept of synthesis as Benjamin applies it, one that scintillates in his use of the notion of synthetic experience. On the one hand, there is the synthesis that constitutes the unity of the related event by embedding it in the storyteller's life, making him, as it were, the transcendental subject of the narrative, where what is narrated - what is related - is precisely the relation to the subject. In this sense, which comes close to the concept of Kantian transcendental synthesis, experience can only be synthetic, i.e. the result of a synthesis. Proust's narrative, on the other hand, works differently, as we have seen, following Blanchot. By reducing narration to 'pure narrative', where every residue of voluntary memory vanishes in favour of that "outpouring of the imagination in which a field is established between [past and present]" ${ }^{41}$ - as it characterises the essence of 
involuntary memory - distant points "separated by the entire course of lived life" ${ }^{42}$ come to constitute a life, ultimately life as a whole, but a life entirely immanent to narration, in an imaginary space entirely disconnected from the storyteller's, i.e. the (empirical) writers' life.

Storytelling is thus a kind of synthesis. It brings about the cohesion of past and present generations. But the synthetic reduplication of this gesture of storytelling - the transformation of the life of the storyteller into the figure of the storyteller - seems to produce a very specific conception of what, for Proust, 'the present generation' was. For Benjamin, it is the perceived unavailability of a primordial mode of narration which encapsulates the experience of technological progress. The separation of generations from each other - which ensues from the ever increasing speed at which any knowledge linked to living environments seems to make the very essence of the story obsolete. This essence lies in the quality of speaking to the listener by virtue of the marks of the storyteller's life that the story makes on its fabric. Viewed against this backdrop, art mobilises its resources precisely as a consequence of the unavailability of such exteriority. ${ }^{43}$ The relations of subject and world, of past events and the listener's experience, thus need to be reproduced artificially. The structure of Proust's "autobiographical work" as an "unconstruable synthesis" 44 has the same status for Benjamin as for Blanchot: the status of a synthetic life - a life detached from every particular life. As a work it materialises this very detachment, and where it takes the form of pure narrative, it (re)produces life as absolute interiority, as completely contained within the work. In this way, the idea of involuntary memory, epitomising this reduction to pure narrative by excluding every element of command from a subject, carries the index of the historic situation, which is that of the loss of the subjective ability to narrate:

It is by no means evident to be dependent on chance in this matter [of taking hold of one's experience through recollection]. Man's inner concerns do not have their issueless private character by nature. They do so only when he is increasingly unable to assimilate the data of the world around him by way of experience. ${ }^{45}$

Here, what Blanchot characterised as 'novelistic density' amounts to the striving for a complete self-subsistence of life within the work. Benjamin's formulation is therefore deceptive. There can be no simple restoration of storytelling and of the storyteller; instead, their historical relevance lies in the fact that, for Benjamin, 'restoration' is at once a fundamental transformation, a metamorphosis of the very essence of storytelling. Blanchot, for his part, argues that Proust's work should be read as the "metamorphosis of the narrator turned into a 'character' of the book, the one who in the story writes a story that is the work itself". ${ }^{46}$ The storyteller as a 'figure' can no longer leave his life's marks on the story; rather, this life re-emerges within the narration, as a token of a natural history collection, as the narrated life of a narrator that is inseparable from narration. But narration, in turn, has retreated to, or rather constituted a space that, by virtue of its pure inanimate exteriority, acquires an utterly unreal and inaccessible dimension: an image of life. ${ }^{47}$ Viewed in this way, immanence amounts to pure exteriority.

In his 1929 essay on "The Image of Proust", Benjamin characterises Proust's writing as a "Penelope work of recollection" that is really a "Penelope work of forgetting", where "the day unravels what the night" has "woven." "It it not only Benjamin and Blanchot's common reference to the myth of Ulysses ${ }^{49}$ which highlights the affinity between their respective readings of Proust. While Blanchot sets out to tackle the question of a 'pure narrative', Benjamin shifts his attention from the subject matter of this or that narrated 
memory to the "actus purus of recollection itself". ${ }^{50}$ Only this pure act of recollection, "not the author of the plot", as Benjamin explicitly points out, is what "constitutes the unity of the text." ${ }^{51}$ Here, the synthesis in question - as we have seen, Benjamin describes Proust's work as an 'unconstruable synthesis' - appears to be formulated in the vocabulary of textual metaphors: the "tapestry of lived life", ${ }^{52}$ which is woven by recollecting and forgetting, derives its figurative persuasiveness from the Latin word textum (web), as Benjamin reminds us. What he observes in Proust is the dissolution of the subject of recollection into textuality. But what exactly does this mean?

\section{Blanchot (II): Empty Totality}

Following Blanchot, we have seen that the exteriority entailed by writing ${ }^{53}$ creates an 'almost sacred reality', one that could be thought of in terms of the structure that Benjamin assigns to allegory. The internal space defined by what Proust calls 'sensation' appears to be the object of narration. But in its artificiality, at least as Benjamin presents it, this allegedly internal space reveals itself as the shadow, or rather, the peculiarly motionless image of real sensation - provided that such realness is understood as a sensation's belonging to an individual self. Presenting itself as the image of a psyche, this pure recollection becomes legible as the materialisation of the very absence of any individual self. Pure recollection is not recollection of a self but rather recollection in spite of a self. The involuntary memory, of which Proust's narrator seems to be the subject, is in fact realised as the continuous (self-)abdication of a subjecthood that is transformed into narration. What appears as the immanence of pure recollection thus poses a boundary value (a property of the image, as Blanchot conceives it) that marks the point where the reader's desire for immersion into the fictional world as well as identification with fictional characters must necessarily be disappointed ${ }^{54}$ Memory, as far as Proust is concerned, has to do with the text's resistance to empathy with the narrator and his characters. ${ }^{55}$ Consequently, Proust's project, as Benjamin understands it, cannot be seen as addressing the realm of (psychological) interiority and hence of subjectivity as such. Rather, "man's inner concerns", ${ }^{66}$ by dint of their construction as pure narration, are turned inside out; the psyche is inverted into physis. Benjamin emphasises Proust's striving to "design the entire inner structure of society as a physiology of chatter." 57 Society, when congealed into an image - a totality - presents itself as nature, as a "petrefied, primordial landscape." ${ }^{58}$ And it is this imaginary dimension of society as a totality, which reveals the nexus of fate and writing. For wherever the writing of fate is supposed to be situated, the idea is always that of a codification that ultimately encompasses a totality, which, by its sheer density, immobilises every element. This applies to Proust's characters:

Proust's characters, which are planted so firmly in their social habitat, influenced by the position of the sun of aristocratic favour, stirred by the wind that blows from Guermantes or Méséglise, and inextricably intertwined in the thicket of their fate. ${ }^{59}$

It is a "vegetative existence" 60 that pertains to these characters, while the narrator, rather than presenting a subjective interiority, can be thought of as the ferment by which this nexus is transformed into an image. Physis, nature, is therefore what things turn into when viewed in their totality, or as totality, and absolute narrative thus meets at least one demand that Adorno formulates when he writes about "The Idea of Natural History", namely to "comprehend historical being in its most extreme historical determinacy, where it is 
most historical, as natural" ${ }^{61}$ Conversely, the appearance of intentionality, and therefore of action, spontaneity, and subjectivity qua praxis, can be understood as the result of a subtraction, the not-all that would characterise actual, i.e. lived, unformed life.

Benjamin and Blanchot both suggest that fiction in modernity constitutes the medium of totality. For Benjamin, once again, it is the integrating quality of what was once experience, which Proust's novelistic project seeks to achieve artificially. Blanchot, in turn, focuses on the instant of separation, in which experience, thus conceived as fiction, cuts itself off from a world in which experiencing, acting beings could subsist and which, by virtue of its very unavailability, can be termed real and historical. For Blanchot, the totality that fiction constitutes qua pure narrative is therefore never a totality of something but rather a pure totality, even if its manifestations may be fragmentary. It is a universal negation, severed from the realm of determinate negation, which would constitute subjectivity and thus action. A 'vegetative existence', such as the mode of being that Benjamin ascribes to Proust's characters - one that entails the inability to act as a subject - derives from the peculiar inactivity, which, according to Blanchot, defines the writer as "master of the imaginary." ${ }^{2}$ In a much more general sense, Blanchot makes the point that the world as a whole - and, when mediated by the experience of a narrator, life as a whole - is at the same time less than the world, less than life:

The truth is that he [the writer] ruins action, not because he deals with what is unreal but because he makes all of reality available to us. Unreality begins with the whole. The realm of the imaginary is not a strange region situated beyond the world, it is the world itself, but as entire, manifold, the world as a whole. That is why it is not in the world, because it is the world, grasped and realized in its entirety by the global negation of all the individual realities contained in it, by their disqualification, their absence, by the realization of that absence itself, which is how literary creation begins $[. . .]^{63}$

The writer is thus the model of an inability to act precisely because the global negation by which every fictional sentence negates the world as a whole through language, whilst also negating language as a whole by making it an image of language, leaves no room for action. It is this sudden transformation that Blanchot repeatedly describes as " désœuvrement" ${ }^{64}$ an inability that ultimately characterises every notion of individual selfhood in modernity, because such selfhood cannot persist without becoming entangled in the medium of the imaginary. ${ }^{65}$ But perhaps the very materialisation of this entanglement may bear the promise of breaking this spell? If, for Benjamin, Proust's mémoire involontaire constitutes a time outside of history [geschichtslos], then it is Blanchot who focuses on literary creation - the 'space of literature' - as an interstice between the realms of nature and history. His theory of the "two versions of the imaginary" 66 concerns this very nexus.

Proust attempts "to produce experience synthetically [...] under today's conditions, for there is less and less hope that it will come into being naturally." ${ }^{67}$ But by making all of it available, what becomes available is, in a certain sense, its very unavailability: the empty totality of a world and a life that is completely self-sufficient. 'Under today's conditions' means, at once, that he produces the psychology of experience as an image of experience that exposes the mythic fabric of the psyche itself. Such an image simultaneously exposes the passivity of the individual self as it emerges from people's separation from economic production, while the dissimulation of this very separation makes for the appearance of spontaneity and individual selfhood. When considered against the backdrop of the complete unavailability of primordial, unmediated experience, which Benjamin describes, 
what appeared at first sight as the image of a psyche, reveals the psyche as image. To say, as Benjamin does, that Proust's work produces experience synthetically therefore means that it produces an absolute experience, and therefore an immanent experience - one that refuses to be the experience of a subject which transcends the work. Such a claim is in accordance with Benjamin's critical intention, developed early on in his essay "On The Program of the Coming Philosophy", which contains a reading of Kant's concept of experience under the aspect of eliminating "the subject nature of the cognizing consciousness" 68 as one of the "primitive elements of an unproductive metaphysics." 69 Contrary to Deleuze's view of desire, which is informed by Proust's theory of memory, it has to be said that if desire does in fact occur within an assembly, an agencement, which in Proust's case - takes the shape of pure narrative, then one (i.e. a conscious subject) can only experience one's exclusion from desire, one's separation from it. Reading (as a subject) therefore means to experience this limitation of experience, to experience this withdrawal and refusal; and if subjective experience operates via synthesis, then it is the experience of a moment of "nonsynthesis" 70 that comes into focus here. The synthetic experience brought about in Proust's work is therefore nothing less than the realisation of what Benjamin elsewhere describes as "profane illumination", ${ }^{71}$ one that reveals the effects of "that most terrible drug - ourselves - which we take in solitude." 72

\section{BIBLIOGRAPHY}

ADORNO, Theodor W., "The Idea of Natural History”, in: Robert Hullot-Kentor, Things Beyond Resemblance. Collected Essays on Theodor W. Adorno (New York: Columbia University Press, 2006), pp. 252-269.

ADORNO, Theodor W., Kierkegaard. Construction of the Aesthetic, trans. Robert Hullot Kentor (Minneapolis: University of Minnesota Press, 1989).

BENJAMIN, Walter, The Arcades Project, trans. Howard Eiland, Kevin MacLaughlin (Cambridge, MA: Belknap Press of Harvard University Press, 1999).

BENJAMIN, Walter, Selected Writings 2.1, 1927-1930, eds. Howard Eiland, Michael W. Jennings \& Gary Smith (Cambridge, MA: Belknap Press of Harvard University Press, 1999).

BENJAMIN, Walter, The Origin of German Tragic Drama, trans. John Osborne (London: Verso, 1998).

BENJAMIN, Walter, Selected Writings 1, 1913-1926, eds. Marcus Bullock \& Michael W. Jennings (Cambridge, MA: Belknap Press of Harvard University Press, 1996).

BENJAMIN, Walter, Illuminations, ed. Hannah Arendt, trans. Harry Zohn (New York: Schocken Books, 1968).

BLANCHOT, Maurice, The Book to Come, trans. Charlotte Mandell (Stanford: Stanford University Press, 2003).

BLANCHOT, Maurice, The Work of Fire, trans. Charlotte Mandell (Stanford: Stanford University Press, 1995). 
BLANCHOT, Maurice, The Space of Literature, trans. Ann Smock (Lincoln: University of Nebraska Press, 1982).

DELEUZE, Gilles, Proust and Signs, trans. Richard Howard (Minneapolis: University of Minnesota Press, 2000).

FOUCAULT, Michel, “The Thought from Outside”, in: Foucault/ Blanchot, trans. Jeffrey Mehlman \& Brian Massumi (Cambridge, MA: MIT Press, 1987), pp. 7-58.

FREUD, Sigmund, An Outline of Psychoanalysis, trans. James Strachey (London: Chatto \& Windus, 1969).

POULET, Georges, L'éspace proustien (Paris: Gallimard, 1983).

WEBER, Samuel, Benjamin's -abilities (Cambridge: Harvard University Press, 2008).

ŽIŽEK, Slavoj, Less Than Nothing: Hegel and the Shadow of Dialectical Materialism (London: Verso, 2012).

\section{ENDNOTES}

1. Cf. Walter Benjamin, “Goethe’s Elective Affinities”, in: Selected Writings 1, 1913-1926, eds. Marcus Bullock \& Michael W. Jennings (Cambridge, MA: Belknap Press of Harvard University Press, 1996), p. 297.

2. Cf. ibid.

3. Michel Foucault, “The Thought From Outside”, in: Foucault/Blanchot, trans. Jeffrey Mehlman \& Brian Massumi (Cambridge, MA: MIT Press, 1987), p. 15.

4. It is worth noting that Slavoj Žižek proposes a reading of Hegel's 'Absolute Knowing' [absolutes Wissen] that hinges on precisely this thought. Far from being "the magical ability of Spirit to generate all content", it is rather "Spirit's thorough passivity" that is reached in Absolute Knowing: "The stance of 'Absolute Knowing' thus fully coincides with thorough (absolute) historicism: there is no transcendental 'big Other,' there are no criteria that we can apply to historical phenomena to judge them; all such criteria must be immanent to the phenomena themselves." (Slavoj Žižek, Less Than Nothing: Hegel and the Shadow of Dialectical Materialism [London: Verso, 2012], p. 387.)

5. Cf. Walter Benjamin, "Surrealism: The Last Snapshot of the European Intelligentsia", in: Selected Writings 2.1, 1927-1930, eds. Howard Eiland, Michael W. Jennings \& Gary Smith (Cambridge, MA: Belknap Press of Harvard University Press, 1999), p. 217.

6. Walter Benjamin, The Arcades Project, ed. Rolf Tiedemann, trans. Howard Eiland \& Kevin McLaughlin (Cambridge, MA: Belknap Press of Harvard University Press, 1996), p. 389.

7. Benjamin, "Surrealism", p. 217.

8. Perhaps this specification should be seen in the light of an earlier account of historical knowledge given in "On the Program of the Coming Philosophy", one that strives to formulate the counterpart to Kantian philosophy in that it is directed towards "the integrity of an experience that is ephemeral", rather than a "certainty of knowledge that is lasting". (Walter Benjamin, "On the Program of the Coming Philosophy", in: Selected Writings 1, 1913-1926, eds. Marcus Bullock \& Michael W. Jennings [Cambridge, MA: Belknap Press of Harvard University Press, 1996], p. 100.)

9. Sigmund Freud, An Outline of Psychoanalysis, trans. James Strachey (London: Chatto \& Windus, 1969), p. 13.

10. Cf. Samuel Weber, Benjamin's -abilities (Cambridge, MA: Harvard University Press, 2008), p. 171. 
11. "The situation of consciousness as patterned and checkered by sleep and waking need only be transferred from the individual to the collective." (Benjamin, The Arcades Project, p. 389.) The German word Zustand perhaps implies even more immobility than the English situation.

12. Benjamin, The Arcades Project, p. 389.

13. Cf. L'abécédaire de Gilles Deleuze, directed by Pierre-André Boutang (Paris: Montparnasse, 2004), DVD.

14. George Poulet, L'Espace proustiens (Paris: Gallimard), p. 40. [My translation.]

15. Ibid, p. 38. [My translation.]

16. Cf. Maurice Blanchot, "The Experience of Proust", in: The Book to Come, trans. Charlotte Mandell (Stanford: Stanford University Press, 2003), p. 11.

17. Ibid.

18. Ibid.

19. Cf. ibid, p. 13.

20. Cf. ibid, p. 12 .

21. Ibid.

22. Cf. ibid, p. 253.

23. Ibid, p. 13.

24. Cf. ibid, p. 19.

25. Ibid.

26. Cf. ibid, p. 14.

27. Ibid, p. 14. Deleuze also comments on the function of style, metaphor and metamorphosis in Proust: "style is essentially metaphor. But metaphor is essentially metamorphosis and indicates how the two objects exchange their determinations, exchange even the names that designate them, in the new medium that confers the common quality upon them." (Gilles Deleuze, Proust and Signs, trans. Richard Howard [Minneapolis: University of Minnesota Press, 2000], p. 48.)

28. Blanchot, "The Experience of Proust", p. 15.

29. Cf. ibid, p. 12. It is significant that Blanchot terms this fictional reality "almost sacred". As a purely poetic reality, i.e. one that has no other manifestation than the combination of written words, it corresponds with the nature of sacred texts as Benjamin characterises them: "It is possible, without contradiction, to conceive of a more vital, freer use of the revealed spoken language, in which it would lose none of its dignity. This is not true of its written form, which allegory laid claim to being. The sanctity of what is written is inextricably bound up with the idea of the strict codification. For sacred script always takes the form of certain complexes of words which ultimately constitute, or aspire to become, one single and inalterable complex." (Walter Benjamin, The Origin of German Tragic Drama, trans. John Osborne [London: Verso, 1998], p. 175.)

30. The "transformation of time into an imaginary space (the space unique to images)" is what Blanchot highlights in the concept of metaphor that is crucial for Proust, where "it is no longer a matter of applying psychology; on the contrary, there is no more interiority, for everything that is interior is deployed outwardly, takes the form of an image." (Blanchot, "The Experience of Proust", p. 14.)

31. Ibid, p. 16.

32. Walter Benjamin, “On Some Motifs in Baudelaire”, in: Illuminations, ed. Hannah Arendt, trans. Harry Zohn (New York: Schocken Books, 1968), p. 157.

33. Ibid.

34. Ibid.

35. Ibid.

36. Ibid, p. 159.

37. Ibid. [Emphasis added]

38. Ibid.

39. Blanchot, "The Experience of Proust", p. 17. 
40. Benjamin, "On Some Motifs in Baudelaire", p. 157.

41. Blanchot, "The Experience of Proust", p. 18.

42. Ibid, p. 12.

43. Cf. Foucault, "The Thought From Outside", p. 7

44. Cf. Walter Benjamin, "The Image of Proust", in: Illuminations, ed. Hannah Arendt, trans. Harry Zohn (New York: Schocken Books, 1968), p. 201.

45. Benjamin, "On Some Motifs in Baudelaire", p. 158.

46. Blanchot, "The Experience of Proust", p. 15.

47. One might even think of the allegorical character that life acquires through immobilisation, inverting it into its opposite - a point that is manifested in the pictorial tradition of the still life or nature morte. Elsewhere in his essay on Baudelaire, Benjamin explicitly states that the time of the mémoire involontaire is "outside history" [geschichtslos]. (Benjamin, "On Some Motifs in Baudelaire", p. 184). The retreat that is embodied by life, conceived of as an image, thus indicates a space of nature, according to Benjamin's definition of beauty: "Beauty in its relationship to nature can be defined as that which 'remains true to its essential nature [wesenhaft sich selbst gleich] only when veiled." (ibid, p. 199).

48. Cf. Walter Benjamin, "The Image of Proust", p. 202.

49. Blanchot treats the myth of Ulysses in the essay preceding "The Experience of Proust", where he discusses the motif of the song of the Sirens to which, incidentally, Proust's narrator relates his crucial experience as a writer-to-be in the final volume of the Recherche. (cf. Maurice Blanchot, "Encountering the Imaginary", in: The Book to Come, trans. Charlotte Mandell [Stanford: Stanford University Press, 2003], pp. 3-10.)

50. Benjamin, “The Image of Proust", p. 203.

51. Ibid.

52. Ibid, p. 202.

53. For a further examination of this notion of exteriority, see: Foucault, "The Thought From Outside".

54. Under these circumstances, every kind of moral or psychological evaluation of literary characters (and, indeed, of the narrator as a character) is unthinkable. Benjamin refutes precisely this approach to literary criticism in his study on the German Trauerspiel, where he insists that "fictional characters exist only in literature. They are woven as tightly into the totality of the literary work [ins Ganze ihrer Dichtung] as are the subjects of Gobelins into their canvas, so that they cannot be removed from it as individuals." (Benjamin, The Origin of German Tragic Drama, p. 105.)

55. For the same reason, Benjamin insists on the fact that the dialectical image is an "image that is read", where this moment of reading coincides with the "now of recognisability". (Benjamin, The Arcades Project, p. 463.)

56. Benjamin, "On Some Motifs in Baudelaire", p. 158.

57. Benjamin, "The Image of Proust", p. 206.

58. Benjamin, The Origin of German Tragic Drama, p. 166.

59. Ibid, 208.

60. Ibid.

61. Theodor W. Adorno, "The Idea of Natural History", in: Robert Hullot-Kentor, Things Beyond Resemblance. Collected Essays on Theodor W. Adorno, (New York: Columbia University Press, 2006), p. 260.

62. Maurice Blanchot, "Literature and the Right to Death", in: The Work of Fire, trans. Charlotte Mandell (Stanford: Stanford University Press, 1995), p. 316.

63. Ibid.

64. Blanchot describes the structure of the work - the literary work - as consisting of the pure declaration of being and thus emerging from the rupture with all 'actual' being. It thereby 
exposes the being of language as a "region anterior to the beginning where nothing is made of being, and in which nothing is accomplished. It is the depth of being's inertia [désœuvrement]." (Maurice Blanchot, The Space of Literature, trans. Ann Smock [Lincoln: University of Nebraska Press, 1982], p. 46.)

65. Here, Benjamin's thesis on the "issueless private character of Man's inner concerns" can be related to Adorno's study on Kierkegaard, Construction of the Aesthetic, which Benjamin reviewed. (cf. Walter Benjamin, "Kierkegaard: The End of Philosophical Idealism", in: Selected Writings 3, 1935-1938, eds. Howard Eiland \& Michael W. Jennings, [Cambridge, MA: Belknap Press of Harvard University Press], pp. 703-705.) One can recognize an anticipation of Blanchot's take on the imaginary in Adorno's interconnection of the "semblance of things" with the dimension of "isolated privacy": "He who looks into the window mirror, however, is the private person, solitary, inactive, and separated from the economic process of production. The window mirror testifies to objectlessness - it casts into the apartment only the semblance of things - and isolated privacy." (Theodor W. Adorno, Kierkegaard: Construction of the Aesthetic, trans. Robert Hullot-Kentor [Minneapolis: University of Minnesota Press, 1989], p. 42.)

66. Cf. Blanchot, "The Space of Literature", p. 254.

67. Benjamin, “On Some Motifs in Baudelaire”, p. 157.

68. Benjamin, "On the Program of the Coming Philosophy", p. 103.

69. Ibid, p. 102.

70. Ibid.

71. Cf. Benjamin, The Arcades Project, p. 216.

72. Ibid.

\section{ABSTRACTS}

The article seeks to delineate a correspondence between Walter Benjamin and Maurice Blanchot's accounts of subjectivity through the prism of their respective readings of Marcel Proust. While Benjamin focuses on the peculiar artificiality of experience produced in Proust's Recherche, Blanchot gives an account of the transformation of the narrator, which produces a 'pure narrative' and thus turns subjective interiority outward into writing. By relating their approaches to the problem of totality, Benjamin and Blanchot both indicate a concept of history, and of historical cognition, which is linked to the problem of writing, of fiction or narration and to a specific understanding of the literary work.

\section{INDEX}

Keywords: Benjamin Walter, Blanchot Maurice, Proust Marcel, image, recollection 